\title{
Impact Evaluation of a Refrigeration Control System Installed at Vitamilk Dairy, Incorporated Under the Energy \$avings Plan
}

\author{
D. R. Brown \\ D. R. Dixon \\ G. E. Spanner
}

January 1995

Prepared for Sheila Riewer

Program Evaluation Section

Office of Energy Resources

Bonneville Power Administration

U.S. Department of Energy

under Contract DE-AC06-76RLO 1830

Pacific Northwest Laboratory

Richland, Washington 99352 


\section{DISCLAIMER}

This report was prepared as an account of work sponsored by an agency of the United States Government. Neither the United States Government nor any agency thereof, nor Battelle Memorial institute, nor any of their employees, mákes any warranty, expressed or implied, or assumes any legal liability or responsibility for the accuracy, completeness, or usefulness of any information, apparatus, product, or process disclosed, or represents that its use would not infringe privately owned rights. Reference herein to any specific commercial product, process, or service by trade name, trademark, manufacturer, or otherwise does not necessarily constitute or imply its endorsement, recommendation, or favoring by the United States Government or any agency thereof, or Battelle Memorial Institute. The views and opinions of authors expressed herein do not necessarily state or reflect those of the United States Government or any agency thereof.

PACIFIC NORTHWEST LABORATORY

operated by

BATTELLE MEMORIAL INSTITUTE

for the

UNITED STATES DEPARTMENT OF ENERGY

under Contract DE-ACO6-76RLO 1830 


\section{Summary}

This impact evaluation of a refrigeration control system (RCS) that was recently installed at Vitamilk Dairy, Incorporated (Vitamilk) was conducted for the Bonneville Power Administration (Bonneville) as part of an evaluation of its Energy \$avings Plan (ESP) Program. The RCS installation at Vitamilk uses microcomputer-based controls to automate refrigeration equipment that was previously controlled manually. The objective of this impact evaluation was to assess how much electricity is being saved at Vitamilk as a result of the E\$P and to determine how much the savings cost Bonneville and the region. The impact of the project was evaluated with a combination of engineering analysis, financial analysis, interviews, and submittal reviews (Vitamilk's proposal and completion report).

Based on this impact evaluation, energy savings from this project are expected to be 800,000 kilowatt-hours/year (kWh/yr) or $\overline{0} .09$ average megawatts (aMW). On a unit savings basis, this project will save $9.7 \mathrm{kWh} /$ tonne $(8.8 \mathrm{kWh} /$ ton) of milk and ice cream produced, based on the product mix for June 1992 through May 1993. These savings represent a 28\% reduction compared to what.energy consumption per tonne of product would have been without the RCS. (Note that the actual energy savings per tonne of product could vary significantly, depending on the ratio of milk and ice cream production, because the refrigeration-related electrical load for a tonne of ice cream is roughly a factor of 15 higher than for a tonne of milk.)

The project was installed in 1992 for a total cost of $\$ 129,330$, and Vitamilk received payment of $\$ 62,974$ from Bonneville in 1993 for the acquisition of energy savings. The real levelized cost of these energy savings. to Bonneville is 8.5 mills/kWh (in 1993 dollars) over the project's assumed 15-year life, and the real levelized cost to the region is 17.9 mills/kWh (in 1993 dollars), not including transmission and distribution effects.

Based on the expected project installation costs and energy savings benefits, the RCS would not have been implemented by Vitamilk without the E\$P acquisition payment. The expected acquisition payment reduced the estimated payback period from 7.0 to 2.8 years. Although Vitamilk would generally require an energy conservation project to have a payback period of two years or less, the slightly longer payback period was accepted in this case.

\section{DISCLAIMER}

This report was prepared as an account of work sponsored by an agency of the United States Government. Neither the United States Government nor any agency thereof, nor any of their employees, makes any warranty, express or implied, or assumes any legal liability or responsibility for the accuracy, completeness, or usefulness of any information, apparatus, product, or process disclosed, or represents that its use would not infringe privately owned rights. Reference herein to any specific commercial product, process, or service by trade name, trademark, manufacturer, or otherwise does not necessarily constitute or imply its endorsement, recom-

I mendation, or favoring by the United States Government or any agency thereof. The views and opinions of authors expressed herein do not necessarily state or reflect those of the United States Government or any agency thereof.

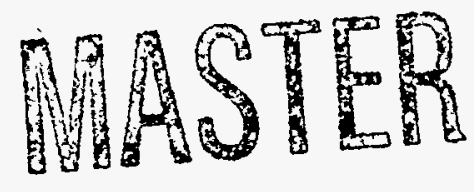





\section{DISCLAIMER}

Portions of this document may be illegible in electronic image products. Images are produced from the best available original document. 


\section{Contents}

Summary $\quad \ldots \ldots \ldots \ldots \ldots \ldots \ldots \ldots \ldots \ldots \ldots \ldots \ldots \ldots \ldots \ldots \ldots \ldots \ldots$ iii

1.0 Introduction $\ldots \ldots \ldots \ldots \ldots \ldots \ldots \ldots \ldots \ldots \ldots \ldots \ldots \ldots \ldots \ldots \ldots \ldots$

1.1 Approach for Impact Evaluation $\ldots \ldots \ldots \ldots \ldots \ldots \ldots \ldots \ldots \ldots 2$

1.2 Project Description $\ldots \ldots \ldots \ldots \ldots \ldots \ldots \ldots \ldots \ldots \ldots \ldots, 2$

1.3. Summary of Project Impacts $\ldots \ldots \ldots \ldots \ldots \ldots \ldots \ldots \ldots \ldots$

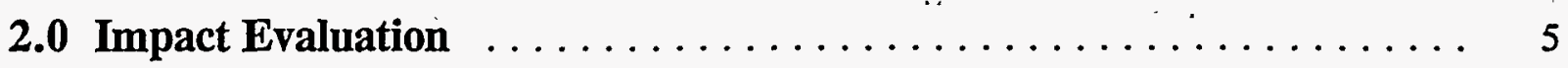

2.1 Energy Savings and Fuel Switching $\ldots \ldots \ldots \ldots \ldots \ldots \ldots \ldots$

2.2 Impacts to the Firm $\ldots \ldots \ldots \ldots \ldots \ldots \ldots \ldots \ldots \ldots \ldots$

2.3 Impacts to the Utility $\ldots \ldots \ldots \ldots \ldots \ldots \ldots \ldots \ldots \ldots \ldots \ldots \ldots \ldots$

2.4 Real Levelized Costs $\ldots \ldots \ldots \ldots \ldots \ldots \ldots \ldots \ldots \ldots \ldots$

2.4.1 Bonneville Perspective $\ldots \ldots \ldots \ldots \ldots \ldots \ldots \ldots \ldots \ldots \ldots .9$

2.4.2 Regional Perspective $\ldots \ldots \ldots \ldots \ldots \ldots \ldots \ldots \ldots \ldots \ldots \ldots$

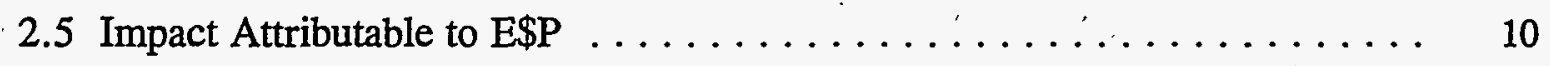

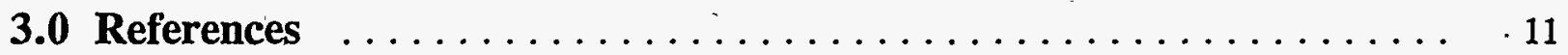

Appendix A - Financial Evaluation Details $\ldots \ldots \ldots \ldots \ldots \ldots \ldots \ldots$ A.1

Áppendix B - Proposal Cover Sheet $\quad \ldots \ldots \ldots \ldots \ldots \ldots \ldots \ldots \ldots \ldots$ B.1 


\section{Tables}

\subsection{Energy Savings Verification Data}

\section{DISCLAIMER}

This report was prepared as an account of work sponsored by an agency of the United States Government. Neither the United States Government nor any agency thereof, nor any of their employees, makes any warranty, express or implied, or assumes any legal liability or responsibility for the accuracy, completeness, or usefulness of any information, apparatus, product, or process disclosed, or represents that its use would not infringe privately owned rights. Reference herein to any specific commercial product, process, or service by trade name, trademark, manufacturer, or otherwise does not necessarily constitute or imply its endorsement, recommendation, or favoring by the United States Government or any agency thereof. The views and opinions of authors expressed berein do not necessarily state or reflect those of the United States Government or any agency thereof. 


\subsection{Introduction}

This report describes Pacific Northwest Laboratory's (PNL's) ${ }^{(a)}$ evaluation of the impact of an energy conservation project installed in 1992 at Vitamilk Dairy, Incorporated (Vitamilk) in Seattle, Washington. The project at Vitamilk is one in a continuing series of industrial energy conservation projects to have its impact evaluated by PNL. All of the projects have received or will receive acquisition payments from the Bonneville Power Administration (Bonneville) under the Energy \$avings Plan (E\$P) Program.

The E\$P is being offered to reduce electricity consumption in the industrial sector of Bonneville's service territory. For the Vitamilk project, the acquisition payment offered under the program was equal to the lesser of $15 \mathrm{c} / \mathrm{kilowatt}-\mathrm{hour}(\mathrm{kWh})$ saved in the first year or $80 \%$ of eligible project costs, both multiplied by $75 \%$. The $75 \%$ factor is applied to E\$P projects when the serving utility (in this case, Seattle City Light) does not obtain all of its power from Bonneville.

The general objective of the impact evaluation was to determine how much electricity is saved by the project and at what cost to Bonneville and to the region. In support of this general objective, answers were sought to the following questions:

1. How much electricity is saved annually by the energy conservation project in terms of kilowatt-hours, kilowatt-hours per unit of plant output (unit savings), and average megawatts (aMW)? Also, did any fuel switching result from implementing this project?

2. If the project improved the productivity of the process, did the firm then increase output of the process to take advantage of the productivity improvement? Did the change in output result in a net increase or decrease in energy used by the process? Did the change in output cause changes in output at the firm's other plants in the region?

3. What was the net impact to the serving utility in terms of electricity consumption (in kilowatt-hours) from implementing the project?

4. What are the real levelized costs of the project from the perspectives of Bonneville and the region?

(a) Pacific Northwest Laboratory is operated for the U.S. Department of Energy by Battelle Memorial Institute under Contract DE-AC06-76RLO 1830. 
5. How much of the project's impact can be attributed to the E\$P?

\subsection{Approach For Impact Evaluation}

Before selecting individual energy conservation projects for impact evaluation, PNL developed a general impact evaluation methodology (Spanner et al. 1988). The major finding of the methodology development was that in the industrial sector, energy conservation projects must be evaluated on a caseby-case basis. Accordingly, the general methodology consists of a variety of impact evaluation techniques that can be applied to individual projects according to the specific circumstances.

To evaluate the impact of the refrigeration control system (RCS) at Vitamilk, four techniques were selected from the general methodology: engineering analysis, financial analysis (see Appendix A), site visit and interview, and review of Vitamilk's submittals. Submetering performed by Seattle City Light in accordance with E\$P program requirements was relied upon by PNL to determine the project's impact. Representatives from PNL visited Vitamilk on June 28, 1993, to view the project firsthand and to interview the Engineering Manager.

\subsection{Project Description}

- The Vitamilk plant in Seattle produces milk, ice cream, and related dairy products. The principal milk production operations are receiving and storing raw milk from dairies, separating milk fat, pasteurizing, homogenizing, packaging, cooling, and storing product. Nonfat milk, milk fat, sugar, and nonfat solids (mostly lactose, milk proteins, and milk salts) are mixed to prepare ice cream. This mixture also proceeds through pasteurizing, packaging, cooling, and product storing steps.

In the energy conservation project at Vitamilk, an RCS was installed to automatically control operation of the refrigeration system that cools milk and ice cream products. The RCS uses a microcomputer-based control system which includes a central computer, video display terminal, multiplexers, temperature and pressure sensors, control and power cabling, software, and a printer.

Previously, the refrigeration system was manually controlled, resulting in inefficient operation. The RCS improved refrigeration system efficiency via the following mechanisms: 1) Compressors are turned off as the refrigeration load decreases to maximize the loading and efficiency on the remaining operating units; 2) Higher efficiency units are preferentially operated to meet the required cooling load; 
3) Compressor suction pressure is allowed to increase (if the evaporating temperature can be raised) to reduce compressor head and power consumption; 4) Compressor discharge pressure is allowed to decrease (if lower outside temperatures facilitate heat rejection at the condensers) to reduce compressor head and power consumption; 5) Evaporator fans are turned off as allowable (if adequate cooling can be maintained) to directly reduce fan power and fan motor waste heat that must be removed by evaporators; 6) The evaporator defrost cycle is terminated as soon as ice is removed from the coils to minimize waste heat that must be removed by evaporators; 7) Liquid ammonia flow to the evaporators is controlled to minimize frost build-up; 8) The condenser spray pumps and fans are turned off if adequate heat rejection is possible without these auxiliary units running; 9) System equipment is monitored to identify problems quickly and reduce time operating at nonoptimum conditions.

Vitamilk submitted two documents to Bonneville: a proposal and a completion report. The proposal described the energy conservation project and presented Vitamilk's cost and benefit expectations. Included was a calculation of the project's expected simple payback. A completion report was submitted to Bonneville after the project was installed and Vitamilk had verified the resulting energy savings. This document listed the actual costs of the project along with a calculation of the energy savings that had been achieved. A copy of the cover sheet from the proposal is included in Appendix B.

Energy savings were verified by metering refrigeration compressor electricity consumption for a three-week period in March 1993. During the first two weeks, the system was controlled automatically with the RCS. During the final week, the RCS was disabled and the system was manually controlled. This allowed energy consumption to be measured with and without the effect of the RCS. Average daily ambient air temperatures were also recorded to document operating conditions during the two periods. Production levels were reported as being constant during the verification period but were not presented in the completion report. Annual energy savings were estimated based on the difference in the average power consumption for the two periods, extrapolated for the entire year. Statistical analysis documented in the completion report yielded a range of 621,000 to $810,000 \mathrm{kWh} / \mathrm{yr}$; the lower figure was officially reported. Potential adjustments to the annual energy savings estimate based on variations in ambient temperature and production are discussed in Section 2.0.

The project cost Vitamilk a total of $\$ 129,330$ in 1992 and Bonneville paid $\$ 62,974$ in 1993 for the energy saved. Vitamilk's cost includes $\$ 126,330$ for equipment purchase and installation, and $\$ 3,000$ for administrative duties associated with the project. The latter was not included in the completion report, but was identified during the site visit and interview. The acquisition payment was calculated by first multiplying the estimated annual energy savings from the proposal $(559,764 \mathrm{kWh})$ by $15 \mathrm{c} / \mathrm{kWh}$, which was less than the alternative based on paying $80 \%$ of the project cost. This 
intermediate figure was multiplied by the $75 \%$ cost-sharing fraction applicable for utilities (such as Vitamilk's utility, Seattle City Light) that do not obtain all of their power from Bonneville. Thus, the overall calculation was $559,764 \mathrm{kWh} * \$ 0.15 / \mathrm{kWh} * 0.75=\$ 62,974$.

\subsection{Summary of Project Impacts}

This E\$P project is expected to save $800,000 \mathrm{kWh}$ annually or 0.09 aMW, based on the analysis conducted for this impact evaluation. Over the assumed 15 year life of this project, the levelized cost to Bonneville is 8.5 mills $/ \mathrm{kWh}$ ( 1 mill $=1 / 1000$ of a dollar), and the cost to the region is 17.9 mills/kWh. These costs are in real 1993 dollars and do not include additional savings that accrue if transmission and distribution losses are considered. The levelized cost to Bonneville, including transmission and distribution losses, is $7.9 \mathrm{mills} / \mathrm{kWh}$, and the cost to the region is $16.6 \mathrm{mills} / \mathrm{kWh}$.

Without the acquisition payment from Bonneville, this project did not meet Vitamilk's payback criteria; however, payback was acceptable with the acquisition payment. Therefore, we conclude that the RCS would not have been installed in the absence of the E\$P. 


\subsection{Impact Evaluation}

The following section addresses the five major objectives of the impact evaluation, as previously stated in Section 1.0.

\subsection{Energy Savings and Fuel Switching}

How much electricity is saved annually by the project in terms of kilowatt-hours, kilowatthours per unit of plant output, and average megawatts? Also, did any fuel switching result from implementing this project?

\section{Energy Savings}

As indicated in Section 1.2, energy savings were estimated (in the completion report) to be between 621,000 and $810,000 \mathrm{kWh} / \mathrm{yr}$ based on metering conducted during the first three weeks of March 1993. Refrigeration system energy consumption was measured for two weeks with the RCS operating and one week with the RCS disabled. In general, the validity of using "before and after" measurements of this type requires that processing conditions be the same (or nearly so) during the two test periods and representative of the entire year. If these conditions are not met, the energy savings indicated by the raw data should probably be adjusted.

The critical process conditions affecting the refrigeration-related electrical load at a dairy are the production of milk and ice cream and the ambient temperature, as well as the characteristics of the refrigeration equipment. The refrigeration load can be broken into product cooling and product temperature maintenance parts. The former is fixed per unit of milk or ice cream production, while the latter varies seasonally depending on ambient temperature. The seasonal variation in ambient temperature also affects the efficiency of the refrigeration system and the electricity required per unit of refrigeration provided.

Milk and ice cream production, ambient temperature, and energy consumption data are presented in Table 2.1 for the verification period. Weekly averages during the test period and annual averages are also presented for comparison. Again, the RCS was on during the first two weeks and off during the third week of the test period. 
Table 2.1. Energy Savings Verification Data

\begin{tabular}{|c|c|c|c|c|c|c|c|c|}
\hline \multirow[b]{2}{*}{ Date } & \multicolumn{2}{|c|}{ Milk } & \multicolumn{2}{|c|}{ Ice Cream } & \multicolumn{2}{|c|}{ Ambient Temperaure } & \multirow[b]{2}{*}{ Average kW } & \multirow[b]{2}{*}{ RCS } \\
\hline & Liters & Gallons & Liters & Gallons r & ${ }^{\circ} \mathrm{F}$ & ${ }^{\circ} \mathrm{C}$ & & \\
\hline $3 / 1 / 93$ & 226,624 & 59,869 & 22,712 & 6,000 & 43 & 6.1 & 258 & On \\
\hline $3 / 2 / 93$ & 301,653 & 79,690 & 18,927 & 5,000 & 46 & 7.8 & 245 & On \\
\hline $3 / 3 / 93$ & 209,404 & 55,320 & 22,712 & 6,000 & 49 & 9.4 & 267 & On \\
\hline $3 / 4 / 93$ & 316,737 & 83,675 & 22,712 & 6,000 & 50 & 10.0 & 245 & On \\
\hline $3 / 5 / 93$ & 257,830 & 68,113 & 22,712 & 6,000 & 54 & 12.2 & 247 & On \\
\hline $3 / 6 / 93$ & 201,190 & 53,150 & 24,605 & 6,500 & 54 & 12.2 & 205 & On \\
\hline $3 / 7 / 93$ & (1) & (1) & (1) & (1) & 50 & 10.0 & 120 & On \\
\hline 6-day average & 251,104 & 66,336 & 22,938 & 5,917 & 49.3 & 9.6 & 244.5 & On \\
\hline 7-day average & (1) & (1) & (1) & (1) & 49.4 & 9.7 & 226.7 & On \\
\hline $3 / 8 / 93$ & 233,839 & 61,775 & 22,712 & 6,000 & 47 & 8.3 & 174 & On \\
\hline $3 / 9 / 93$ & $267,869^{\circ}$ & 70,765 & 22,712 & 6,000 & 47 & 8.3 & 180 & On. \\
\hline $3 / 10 / 93$ & 234,236 & 61,880 & 11,356 & 3,000 & 50 & 10.0 & 235 & On \\
\hline $3 / 11 / 93$ & 297,640 & 78,630 & 22,712 & 6,000 & 48 & 8.9 & 275 & On \\
\hline $3 / 12 / 93$ & 230,829 & 60,980 & 28,390 & 7,500 & 51 & 10.6 & 285 & On \\
\hline $3 / 13 / 93$ & 215,612 & 56,960 & 5,678 & 1,500 & $48^{\circ}$ & 8.9 & 280 & On \\
\hline $3 / 14 / 93$ & (1) & (1) & (1) & (1) & 49 & 9.4 & 206 & On \\
\hline 6-day average & 246,671 & 65,165 & $-18,927$ & 5,000 & 48.5 & 9.2 & 238.2 & On \\
\hline 7-day average & (1) & (1) & (1) & (1) & 48.6 & $9.2 ;$ & 233.6 & On \\
\hline 12-day average & $248,885^{\prime}$ & 65,750 & 20,664 & 5,459 & 48.9 & 9.4 & 241.4 & On \\
\hline 14-day average & (1) & (1) & (1) & (1) & 49.0 & 9.4 & 230.2 & On \\
\hline $3 / 15 / 93$ & 210,351 & 55,570 & 17,034 & 4,500 & 46 & 7.8 & 322 & Off \\
\hline $3 / 16 / 93$ & 280,379 & 74,070 & 11,356 & 3,000 & 43 & 6.1 & 319 & Off \\
\hline $3 / 17 / 93$ & 221,271 & 58,455 & 30,283 & 8,000 & 48 & 8.9 & 322 & Off \\
\hline $3 / 18 / 93$ & 314,883 & 83,185 & 28,390 & 7,500 & 47 & 8.3 & 337 & Off \\
\hline $3 / 19 / 93$ & 243,075 & 64,215 & 17,034 & 4,500 & 48 & 8.9 & 361 & Off \\
\hline $3 / 20 / 93$ & $.251,422$ & 66,420 & 5,678 & 1,500 & 49 & 9.4 & 316 & Off \\
\hline $3 / 21 / 93$ & (1) & (1) & (1) & (1) & 53 & $\cdot 11.7$ & 272 & Off \\
\hline 6-day average & 253,564 & 66,986 & 18,294 & 4,833 & 46.8 & 8.2 & 329.5 & Off \\
\hline 7-day average & (1) & (1) & (1) & (1) & 47.7 & .8 .7 & 321.3 & Off \\
\hline 12-month average & 247,538 & 65,394 & 16,939 & 4,475 & 50 & 10.0 & & \\
\hline
\end{tabular}


Contrary to statements in the completion report, production during the test period was not constant. Daily milk production varied by a factor of 1.5 and daily ice cream production varied by more than a factor of 5 . Weekly production averages effectively eliminated the variation in milk production and reduced the variation in ice cream production to about $20 \%$. Compared with annual averages, milk production during the test period was about the same, but ice cream production was $10 \%$ to $30 \%$ higher, depending on the week.

Weekly average ambient temperatures were essentially constant during the test period and within two degrees of the average annual temperature for Seattle.

Average power consumption dropped by about $30 \%$ (from $321.3 \mathrm{~kW}$ to $230.2 \mathrm{~kW}$ ) with the RCS. With or without the RCS, a drop in power consumption occurs on Sunday when the production facilities are shut down and the refrigeration related load is caused by the temperature maintenance of milk and ice cream and cooling of ice cream produced late on Saturday:

The differences in ice cream production between the two test periods and between the test periods and the annual average suggest that measured energy consumption should be adjusted to a common ice cream production level. Unfortunately, the data presented in Table 2.1 do not provide a sound basis for making an adjustment. Note that during the second week of the two-week period with the RCS turned on, the average power consumption increases by $3 \%$, while ice cream production drops by $15 \%$ and milk production and ambient temperature remain essentially constant. The measured impact of ice cream production on energy consumption is contrary to the expected result. This suggests either a measurement error for one or more of the variables in Table 2.1 or the existence of additional explanatory variables that were not measured.

Given the anomaly in the measured data and implicit uncertainty in the correct energy consumption for a set of production conditions, adjusting the measured energy consumption data to a common ice cream production level was judged to be inappropriate. Therefore, annual energy savings were estimated based on the difference in average measured power demand with and without the RCS, as follows:

$$
\begin{aligned}
& (321.3-230.2) \mathrm{kW} * 8760 \mathrm{hr} / \mathrm{yr}=798,036 \mathrm{kWh} / \mathrm{yr} \\
& (321.3-230.2) \mathrm{kW} / 1000 \mathrm{~kW} / \mathrm{MW}=0.0911 \mathrm{aMW}
\end{aligned}
$$

(Note: These figures were rounded to $800,000 \mathrm{kWh} / \mathrm{year}$ and $0.09 \mathrm{aMW}$ to reflect the degree of accuracy associated with the measured data.) 


\section{Fuel Switching}

The Vitamilk refrigeration system consists of vapor compression machinery that requires electricity for operation. Therefore, no fuel switching occurred.

\subsection{Impacts to the Firm}

If the project improved the productivity of the process, did the firm then increase output of the process to take advantage of the productivity improvement? Did the change in output result in a net increase or decrease in energy used by the process? Did the change in output cause changes in output at the firm's other plants in the region?

Installation of this project improved the productivity of the production process by reducing electricity consumption per unit of milk and ice cream. Increasing production was not an option, however, because this particular plant was already operating near its capacity. Therefore, the project resulted in a net decrease in energy use for Vitamilk.

\subsection{Impacts to the Utility}

What is the net impact to the serving utility in terms of electricity consumption (in kilowatthours) from implementing the project?

Because the project had no cogeneration or other complicating factors, all of the energy savings from this project will be reflected in reduced load at the utility, Seattle City Light. The net impact to Seattle City. Light from this project is a load reduction of $800,000 \mathrm{kWh} / \mathrm{yr}$.

\subsection{Real Levelized Costs}

What are the real levelized costs of the project from the perspectives of Bonneville and the region? 
Real levelized annual costs are used to compare the attractiveness of various projects or investment alternatives. The levelized cost is the annual cost that would be incurred over the life of the project, taking into account the time value of money (see Appendix A for complete definitions and formula). Levelized costs provide a single figure of merit for comparing energy conservation alternatives. In addition, levelized costs can be used to compare conservation projects with options for new generating capacity and to optimize the ranking of these options. Levelized costs were calculated from the perspectives of Bonneville and the region (Bonneville, Seattle City Light, and Vitamilk).

In the industrial sector, it is not possible to accurately predict the life of a project because any number of external factors could cause the project to have a longer or shorter life than expected at installation. To allow comparisons of levelized costs among projects installed under the E\$P, all projects are assumed by PNL to have a life of 15 years for evaluation purposes. Even though some projects will have longer or shorter lives, 15 years is considered a typical life for projects in the industrial sector.

\subsubsection{Bonneville Perspective}

To determine the real levelized costs to Bonneville and to the region, we must know the project costs (acquisition payment, capital costs, etc.) and the energy savings, and must assume a discount rate and project life. With energy savings of $800,000 \mathrm{kWh} / \mathrm{yr}$, the project's levelized cost from Bonneville's perspective is 8.5 mills/kWh (in 1993 dollars) (see Appendix A). Bonneville's levelized cost decreases to 7.9 mills $/ \mathrm{kWh}$ when transmission and distribution losses are considered. Including these losses allows for the comparison of conservation resources with generation, which is measured at the point of production rather than at the site of the end user (point of delivery).

The levelized costs calculated in this impact evaluation include the àcquisition payment by Bonneville, the metering costs of Seattle City Light, and the estimated administrative and evaluation costs associated with this project.

\subsubsection{Regional Perspective}

To calculate the real levelized cost to the region, the costs to Bonneville, Seattle City Light, and Vitamilk are combined. The acquisition payment by Bonneville is included as a cost to Bonneville and as a reduction in cost to Vitamilk. This approach is taken because the acquisition payment has federal income tax consequences for the company and, therefore, a net cost to the region. Seattle City Light's cost includes preparing program submittals and performing metering. 
The real levelized cost to the region for acquiring annual energy savings of $800,000 \mathrm{kWh}$ is 17.9 mills/kWh saved (1993 \$). Including transmission and distribution losses, the levelized cost decreases to 16.6 mills/kWh saved.

\subsection{Impact Attributable to E\$P}

\section{How much of the project's impact can be attributed to the E\$P?}

Vitamilk uses simple payback to evaluate the cost-effectiveness of energy conservation projects and generally requires a payback period of 2 years or less. When this project was proposed to Bonneville, an investment of $\$ 105,971$ was expected to reduce electricity costs by $\$ 15,114 /$ yr (usage and demand savings combined), for a simple payback of 7.0 years. With the expected Bonneville acquisition payment of $\$ 62,974$, simple payback was reduced to 2.8 years. Although Vitamilk indicated that it generally looks for projects with payback periods of 2 years or less, a slightly longer payback period was accepted. Considering the facts presented above, we conclude that this project would not have been implemented without the acquisition payment from Bonneville and that all of the project's impact can be attributed to the E\$P. 


\subsection{References}

Spanner, G. E., D. R. Brown, D. R. Dixon, B. A. Garrett, R. W. Reilly, J. M. Roop, and S. A. Weakley. 1988. Potential Techniques for Evaluating the Impact of Industrial Energy Conservation Projects under Bonneville's Energy \$avings Plan. Letter Report, PNL-6628, Pacific Northwest Laboratory, Richland, Washington. 
Appendix A

Financial Evaluation Details 


\section{Appendix A}

\section{Financial Evaluation Details}

\section{A.1 Definitions}

Real Levelized Cost - A single figure of merit that expresses the cost per unit of benefit (in this case, energy savings), taking into account the time value of money. This annualized cost (not the "adjusted system real levelized cost") would be constant over the entire project life. An infinite number of cash flow scenarios (costs incurred at different times in the project life) could result in the same annualized cost.

Real Levelized Cost to Bonneville Power Administration (Bonneville) - The annualized costs to Bonneville, both direct and indirect, per unit of energy saved by the energy conservation project. Costs included are the acquisition payment and the program administrative costs, as well as the costs to evaluate the impact of this project.

Real Levelized Cost to the Region - The sum of the annualized costs to Bonneville, Seattle City Light, and Vitamilk per unit of energy saved by the energy conservation project. This would include the same costs to Bonneville as listed above, as well as the initial capital and ongoing incremental production costs to the firm. Any nonelectrical savings or costs that result from the project are not considered in this analysis.

\section{A.2 Real Levelized Cost Formula}

$$
\begin{gathered}
\mathrm{LC}^{\prime}=\{\mathrm{PVCI}+\mathrm{PVICI}+(\mathrm{PVOM}+\mathrm{PVOTE}) \bullet(1-\mathrm{itf})-\mathrm{PVD} \bullet \mathrm{itf}] \\
\ddots /(1-\mathrm{itf})\} \bullet(\mathrm{CRF} / \mathrm{AES})
\end{gathered}
$$

$$
\begin{aligned}
\text { where } \mathrm{LC} & =\text { levelized cost (real \$) } \\
\text { PVCI } & =\text { present value of initial capital costs } \\
\text { PVICI } & =\text { present value of interim capital costs } \\
\text { PVOM } & =\text { present value of operating and maintenance costs } \\
\text { PVOTE } & =\text { present value of one-time expenses } \\
\text { itf } & =\text { combined state and federal income tax fraction }
\end{aligned}
$$

\section{A.1}


PVD $=$ present value of depreciation

CRF. = capital recovery factor (spreads the costs over the project life in real dollar terms)

AES = annual energy savings $(\mathrm{kWh} / \mathrm{yr})$.

\section{A.3 General Assumptions .}

The following general assumptions were made in the real levelized cost calculations:

1. All cash flows are expressed in nominal terms (with inflation) and are discounted to present value at a nominal discount rate of $7.12 \%$ (combines a real discount rate of $3.0 \%$ and an inflation rate of $4.0 \%$ ). The costs are annualized over the life of the project using the capital recovery factor at a real discount rate of $3.0 \%$, resulting in real levelized costs.

2. Annual energy savings ( $\mathrm{kWh} / \mathrm{yr}$ ) are constant over the 15-year life of the project. This assumes no loss in efficiency of the equipment with time.

3. Transmission and distribution losses equal 7.5\%, increasing the energy savings at the source (point. of generation) by a corresponding $7.5 \%$.

4. In the regional cost calculation, the acquisition payment from Bonneville is treated as a cost to Bonneville and, at the same time, a cash inflow to Vitamilk rather than a net-zero cost. This is done because Vitamilk will incur a tax liability from the acquisition payment, thus incurring a net cost to the region.

\section{A.4 Bonneville Real Levelized Cost Calculations}

Input:

$\begin{array}{ll}\text { Acquisition payment paid } & =\$ 62,974(1993 \$) \\ \text { Administrative and evaluation costs } & =\$ 20,297(\mathrm{mix} \text { of } 1992 \$ \text { and } 1993 \$) \\ \text { Tax rate } & =0 \% \\ \text { Annual energy savings } & =800,000 \mathrm{kWh} \\ & =8.5 \mathrm{mills} / \mathrm{kWh}(1993 \$)\end{array}$




\section{A.5 Regional Real Levelized Cost Calculations (Bonneville + Seattle City Light + Vitamilk)}

A. Vitamilk

Input:

Equipment installation $\quad=\$ 126,330(1992 \$)$

Administrative costs $\quad=\$ 3,000(1992 \$)$

Acquisition payment received $=\$ 62,974(1993 \$)$

Tax rate $\quad=34 \%$

Project life $\quad=15$ years

Depreciation $\quad=7$ years

Annual energy savings $\quad=800,000 \mathrm{kWh}$

Output:

Levelized cost $\quad=8.8$ mills $/ \mathrm{kWh}(1993 \$)$

B. Seattle City Light

Input:

Administrative and metering

costs

$=\$ 4,800(1992 \$)$

Tax rate

$=0 \%$

Project life

$=15$ years

Annual energy savings

$=800,000 \mathrm{kWh}$

Output:

Levelized cost $\quad \cdot=0.5$ mills $/ \mathrm{kWh}(1993 \$)$

C. Regional levelized cost $=$ Bonneville levelized cost + Seattle City Light levelized cost + Vitamilk levelized cost

$=8.5 \mathrm{mills} / \mathrm{kWh}+0.5 \mathrm{mills} / \mathrm{kWh}+8.8 \mathrm{mills} / \mathrm{kWh}$

$=17.9$ mills $/ \mathrm{kWh}(1993 \$)$

(Note: Component levelized costs presented do not add exactly to the total due to rounding.) 


\section{A.6 Real Levelized Costs Allowing for Transmission and Distribution Losses}

Input: transmission and distribution losses $\quad=7.5 \%$

Bonneville levelized cost $=8.5 \mathrm{mills} / \mathrm{kWh} / 1.075=.7 .9 \mathrm{mills} / \mathrm{kWh}(1993 \$)$

Regional levelized cost $=17.9$ mills $/ \mathrm{kWh} / 1.075=16.6 \mathrm{mills} / \mathrm{kWh}(1993 \$)$ 


\section{Appendix B}

Proposal Cover Sheet 


\section{Appendix B}

\section{Proposal Cover Sheet}

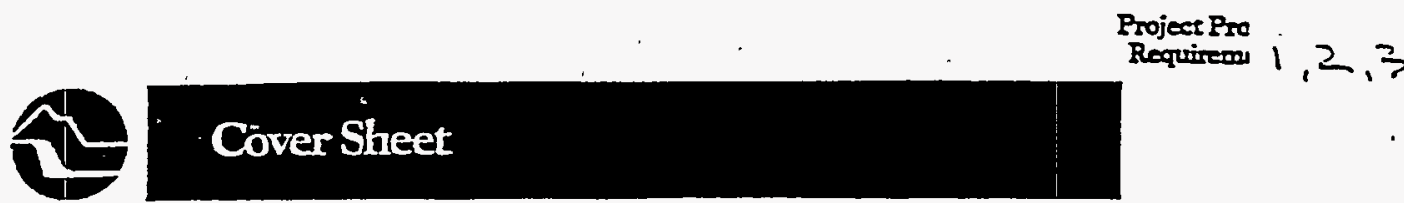

\section{Expiect}

Project Tidle:

Caregorically Exeluded: (See Arachment 2,

Technologies:

Yes No Booklet)

COMPUIERIZSD REFRIGERAION Q

$\square$

CONTTEL $S$ SIEM

Contidential or Proprietary information: $\otimes$ Yes $\square$ No

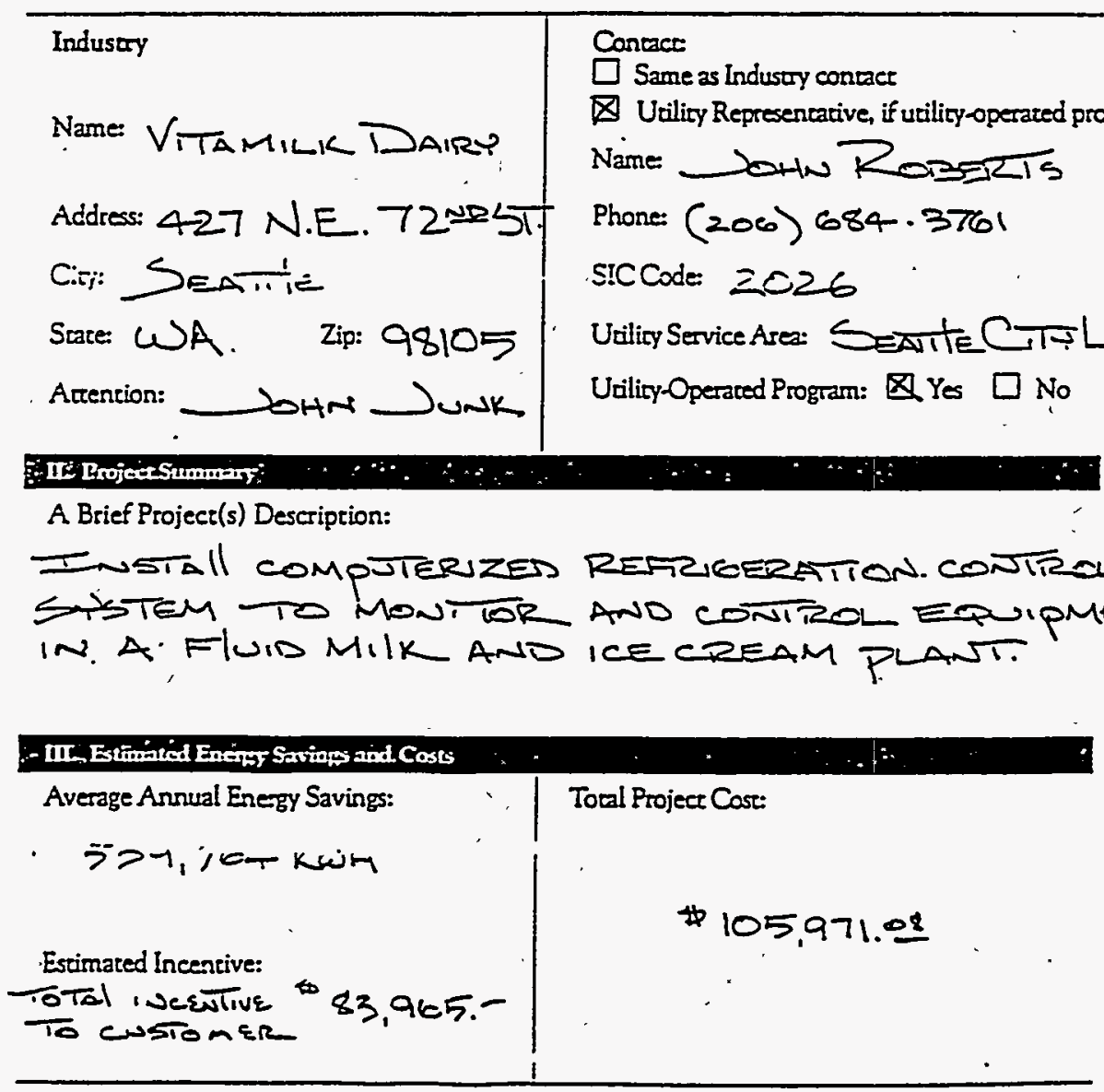

B.1 